\title{
Demokratia and Theatrokratia: The Theatricality of Democracy ${ }^{1}$
}

\author{
Dr Muzaffar Karim \\ Assistant Professor \\ University of Kashmir \\ Jammu \& Kashmir \\ ashar.muzaffar@gmail.com
}

\section{Abstract}

When we think of Democracy as a way of governance, usually modern democratic states come to mind. Most of us believe that democracy is a recent invention. But, the birthplace of democracy is the ancient city of Athens and ironically the birth of democracy is coetaneous with the birth of (Athenian) theatre. This paper tries to establish the connection between theatre and democracy or in other words theatricality and democracy. It tries to elaborate upon the fact that the notion of theatricality is inherent to democratic function and may be its doom as well. Democracy represents progress, a movement in time, a teleology. But, the present problems of famine, violence and other man-made disasters put this movement under suspicion - a progress or a reversion? This question of teleology and time vis-à-vis democracy is argued through Jean Baudrillard's notion of the recycling of time.

Keywords: Theatre, Democracy, Time, Grandnarrative, Spectacle, Baudrillard

Democracy, in its etymology as well as its governance, shares Greek roots all the way. The word originally comes from the Greek word 'demokratia' where demos means 'people' and kratos means 'rule'. The birthplace of democracy is the ancient city of Athens. Around sixth century, Athens was a warring nation of tribal and foreign conflicts and Pisistratus, among others was trying to unify them. Greek poetry had already started with

\footnotetext{
${ }^{1}$ A shorter version of this piece entitled "All Our Monuments are Mausoleums" was published earlier in The Citizen on 17 March, 2020.
} 
Homer around eighth century giving way to Bacchylidian lyrics by seventh century. It is worth noting that during sixth century Athens was not the great nation that we now know. Instead, Sparta, Corinth, Sikyon, and Samos were the cities of importance (Storey and Allan 5). The importance of dates lies in the fact that the rise of Athens is synchronous to the rise of democracy and the rise of democracy is coetaneous with the establishment of the theatre. Around late sixth and early fifth century, Pisistratus established a single festival of Dionysos at Athens, the city of Dionysia. It was "an official celebration" (Storey and Allan 7) around performances which provided the audience a chance to affirm themselves as citizens of the polis. A grand spectacle and theatricality was something that mesmerised, charmed as well as unified a diverse population. Simon Critchley, in Tragedy, the Greeks and Us, summarizes this sentiment when he elaborates on Simon Goldhill's point that theatre was the 'glue of democracy' then. The journey of democracy was accompanied by theatre and its paraphernalia of spectacle and theatricality. Till the time it reaches Elizabethan England, this paraphernalia has become a mere tool to discipline and control people. "We princes are set on stages in the sight and view of all the world" (Greenblatt 152), Queen Elizabeth announced to a delegation of Lords and Commons. Stephen Greenblatt examines Elizabethan power in relation to theatre brilliantly and succinctly in his essay 'Invisible Bullets'. "Elizabethan power" he writes "depends upon its privileged visibility. As in a theatre, the audience must be powerfully engaged by this visible presence..." (Greenblatt 152)Democracy, then, is always in the danger of becoming a mere theatre of tricks and chicaneries - a theatrical democracy to be precise. It was perhaps for this reason that Plato was so afraid of theatre that he calls demokratia (democracy) theatrokratia (Critchley and Webster 15). It means that in a theatrical-democracy the 'truth' is less important than the 'performance'. In fact, the spectacle of a lie, if performed with full theatricality can outwit truth. Democracy begs theatricality. Theatrocracy/democracy, in these (Post) modern times, then becomes, what Guy 
Debord calls 'Society of the Spectacle'. It is a society that "legitimates itself through the production of theatrical or mediatic illusion that gives the impression of legitimacy without any genuine substance" (Critchley and Webster15). Are we moving towards this Debordian society or moving back to PlatonianTheatrokratia. This raises an important question of Time as well as of Ideology.

All the grandnarratives of the world, be it the grandnarrative of speculation (in the form of Hegel's dialectics of the spirit) or the grandnarrative of emancipation (in the form of Kant's emancipation of the rational subject and Marx's emancipation of the working subject (Lyotard xxiii) or Francis Fukuyama's End of History; all these narratives are teleological and according to these narratives we are moving forward. But, there has been no emancipation nor has there been any end. The refugee crisis, terrorism, racial problems, strong nation states, Totalitarianism, extremism - all the ancient problems that should have been an issues of the bygone ages are still persisting. We seem to be stuck or seem to have moved back to the dark ages! World in terms of Time, it seems, like Hamlet is "out of joint" (Shakespeare 57). Jean Baudrillard offers a subtle critique of such a situation through his notion of 'recycled time' which runs opposite to both cyclic as well as teleological time. For Baudrillard, "History has only wrenched itself from cyclical time to fall into the order of the recyclable" (27). However, ironic it may seem, for Baudrillard the 'end' does not occur because of the termination or lack of something. On the contrary, it happens because of the excess of it - the excess of sex in pornography, for example, is the end of sexuality in it - the hyperreal. The excess of events, for example, more importantly the dissemination of any event in real-time through $24 / 7$ news networks and the bombardment and proliferation of commentaries, put an end to history. "The idea is destroyed by its own realization, by its own excess" (Baudrillard, Reader 161) Does Baudrillard vouch for an end then? For Baudrillard, 
this growth is like metastasis, the very growth of the body that ends the body - the body politic or the body social. In all this the time is recycled.

According to Baudrillard, "the defunct ideologies, bygone utopias, dead concepts" like "Church, communism, ethnic groups, conflicts, ideologies" are all here with us and history has become its own dustbin just like "the planet itself is becoming its own dustbin" (Baudrillard, Illusion 26). This historical and intellectual waste scattered all over the dustbin of history poses a larger threat to us than industrial waste. The only possible function left for History is to "either perish under the weight of the non-degradable waste of great empires, the grand narratives, or the great systems" or to "recycle all this waste in the synthetic form of a heteroclite history" (Baudrillard, Illusion 27). It is for this reason the history never comes to an end because the 'leftovers' are all settled here and there is nothing that "will rid us of the sedimentation of centuries of stupidity" (Baudrillard, Illusion 26). The history through its "retroversion ... to infinity" (Baudrillard, Illusion 11) recycles the leftovers, replays itself rectifying or whitewashing any error. Baudrillard's theory helps us to answer the paradox the heteroclite elements of progress and decadence within the democracies all over. The history is recycling and many a time recycles the fascism within democracy, or sometimes simply stupidity because democracy and Human Rights are nothing "but the confused endproduct of the reprocessing of all the residues of history" (Baudrillard, Illusion 27).

If history recycles itself then maybe we have to recycle the theory too and go back to the old societies and their theatricality of power to understand the present paradoxical scenarios of democracies. When considered, the idea does not seem so farfetched - theatre and democracy are twins more like the two strands of DNA. If the problems of democracy result from its origin from theatre, maybe the solution also lies there within. The Netflix series, House of Cards, can be read as a (post) modern critique of present democracy, where the protagonist, Frank Underwood, is able to climb the political rung through diplomacy and 
spectacle. Underwood's proclamation that 'Democracy is overrated', during an episode when he is about to become President without a single vote cast in his favour, is an important question. The question that Underwood asks us as an audience of the drama as well as the audience of the theatrokratia is an essential one. The audience is part of the problem as well as of the solution. For Plato, the only antidote to the poison of deceptive-theatre is philosophy or what in modern vocabulary can be called education. An educated populace, an engaging public is the only audience to this grand theatre. 


\section{Works Cited}

Baudrillard, The Baudrillard Reader. Ed Steve Redhead. Edinburgh: Edinburgh University Press, 2008. Print.

_. The Illusion of the End. Trans. Chris Turner. Oxford: Polity Press, 1994. Print.

Critchley, Simon. Tragedy, The Greeks, and Us. New York: Pantheon Books, 2019. Kindle.

Debord, Guy. Society of the Spectacle. Detroit: Black and Red, 2018. Print.

Greenblatt, Stephen. The Stephen Greenblatt Reader. Ed. Michael Payne. United States of America: Blackwell Publishing, 2005. Print.

Lyotard, Jean-François. The Postmodern Condition: A Report on Knowledge. Trans. Geoff Bennington and Brian Massumi. Minneapolis: University of Minnesota Press, 1984. Print.

Shakespeare, William. Hamlet. New York: W. W. Norton and Company, 2011. Print.

Storey, Ian C. and Arlene Allan. A Guide to Ancient Greek Drama. United States of America: Blackwell Publishing, 2005. Print. 